\title{
Purification, characterization of alkaline protease enzyme from native isolate Aspergillus niger and its compatibility with commercial detergents
}

\section{Kalpana Devi, A. Rasheedha Banu, G.R. Gnanaprabhal, B.V. Pradeep and M. Palaniswamy Department of Microbiology, Karpagam University, Coimbatore 641 021, Tamil Nadu, India. m.palaniswamy@gmail.com}

Abstract: An alkaline protease producing strain Aspergillus niger was isolated from local soil samples and enzyme production was optimized under submerged conditions. Maximum enzyme production of the culture occurred in mesophilic temperature $45^{\circ} \mathrm{C}$ and $\mathrm{pH}$ 8.5. Glucose and ammonium sulfate proved to be the best carbon and nitrogen sources respectively. The molecular weight of the enzyme determined by SDS-PAGE was found to be $38 \mathrm{kDa}$. The enzyme acted optimally at $\mathrm{pH} 10$ and $50^{\circ} \mathrm{C}$. It was thermo stable and retained full activity even at the end of 1 hour of incubation at $40^{\circ} \mathrm{C}$. It was inhibited by $\mathrm{Cu}^{++}$, $\mathrm{Hg}^{++}, \mathrm{Zn}^{++}$, EDTA and sodium azide. The enzyme retained more than $50 \%$ activity after $60 \mathrm{~min}$ incubation at $40^{\circ} \mathrm{C}$ in the presence of detergents such as Tide, Surf, Wheel and Henko indicating its suitability for application in detergent industry.

Keywords - Alkaline protease, Aspergillus niger, purification, characterization, detergent.

Introduction

Alkaline proteases of microbial origin possess considerable industrial potential due to their biochemical diversity and wide applications in tannery and food industries, medicinal formulations, detergents and processes like waste treatment, silver recovery and resolution of amino acid mixtures (Rao et al., 1998; Agarwal et al., 2004) The alkaline proteases find their largest use in house hold laundry with a worldwide annual production of detergents of approximately 13 billion tons (Nehra et al., 2002). Alkaline proteases were in fact the first enzyme produced in bulk. Plant, animal and microbial sources are employed in enzyme production. Microbial proteases are preferred to plant and animal sources to various advantages. A variety of microorganisms such as bacteria, fungi, yeast and Actinomycetes are known to produce these enzymes (Madan et al., 2002). Molds of the genera Aspergillus, Penicillium and Rhizopus are especially useful for producing proteases, as several species of these genera are generally regarded as safe (Sandhya et al., 2005). Aspergillus clavatus ES1 has been recently identified as a producer of an extracellular bleaching stable alkaline protease (Hajji et al., 2007, 2008).

The main draw back with production of bacterial protease is the requirement of cost intensive procedures for separation of enzymes from cells, on the other hand enzyme from fungal origin offer an advantage of separation of mycelium by simple filtration. Besides, the fungus can be grown on inexpensive substrates. The use of alkaline protease as active ingredient in laundry detergent is the single largest application of this enzyme (Nehra et al., 2002). For the production of enzymes for industrial use, isolation and characterization of new promising strain is a continuous process (Kumar et al., 2002). They are generally produced by using submerged fermentation due to its apparent advantages in down stream in spite of the cost intensiveness for medium components (Prakasam et al., 2005).

Reports on bleach stable alkaline protease from fungal sources are scanty (Mulimani et al., 2002). Therefore, a need was felt to explore native fungal isolates, capable of producing alkaline proteases and at the same relatively stable at the operating conditions.

Materials and methods

Isolation of Fungal strain

An alkaline protease producing fungi Aspergillus niger was isolated from local soil, Coimbatore, Tamil Nadu (Palaniswamy et al., 2008).

\section{Enzyme production}

Two hundred $\mathrm{ml}$ of supplemented Reese medium broth in $500 \mathrm{ml}$ Erlenmeyer flask was inoculated with $3 \%$ spore suspension $\left(10^{6}\right.$ spores/ $\mathrm{ml}$ ) prepared from PDA slant, and was grown at $50^{\circ} \mathrm{C}, 72 \mathrm{~h}$ on a rotary shaker at a speed of 150 rpm. The culture was centrifuged at 10,000 rpm for 15 min and supernatant thus obtained was used as crude enzyme extract.

\section{Enzyme assay}

Three $\mathrm{ml}$ of reaction mixture containing $0.5 \%$ casein in $2.95 \mathrm{ml}$ of $0.1 \mathrm{M}$ Tris-Hcl buffer, $\mathrm{pH} 8.5$ and $0.1 \mathrm{ml}$ of enzyme was incubated at $50^{\circ} \mathrm{C}$. After $10 \mathrm{~min}$, the reaction was stopped by adding $3 \mathrm{ml}$ of cold $10 \%$ TCA. After 1 hour, the culture filtrate was centrifuged at $8,000 \mathrm{rpm}$ for $5 \mathrm{~min}$ to remove the precipitate and absorbance of the supernatant was read spectrophotometrically at $280 \mathrm{~nm}$. Enzyme activity was calculated by measuring $\mathrm{mg}$ of tyrosine equivalent released and compared with the standard. One unit $(U)$ of enzyme activity represents the amount of enzyme required to liberate $1 \mu \mathrm{g}$ of tyrosine under standard assay conditions. 


\section{Protein assay}

Protein was quantified by the method of Lowry et al., (1951), with bovine serum albumin as standard.

\section{Optimization of cultural parameters}

Using Reese medium, protease production was studied at different $\mathrm{pH}$ (7-9) and temperature range $\left(30-50^{\circ} \mathrm{C}\right)$. Effect of different carbon and nitrogen sources were also studied.

\section{Partial purification for enzyme characterization}

Ammonium sulfate fractionation:Solid ammonium sulfate was added to the crude extract to $40-80 \%$ saturation. The precipitate was collected by centrifugation, dissolved in minimal volume of $0.1 \%$ Tris- $\mathrm{Hcl}$ buffer $(\mathrm{pH} 9)$ and dialyzed against same buffer at $4^{\circ} \mathrm{C}$.

$D E A E$-cellulose chromatography: The enzyme solution obtained in the above step was applied to DEAE-cellulose column $(2.0 \times 25 \mathrm{~cm})$ pre equilibrated with Tris-Hcl buffer. The enzyme was eluted with the same buffer at a flow rate of 15 $\mathrm{ml} / \mathrm{h}$.

\section{Characterization of purified alkaline protease}

SDS-PAGE: SDS-polyacrylamide

gel electrophoresis (SDS-PAGE) was performed on $12.5 \%(\mathrm{w} / \mathrm{v})$ acrylamide slab gel with $25 \mathrm{mM}$ Tris / $192 \mathrm{mM}$ glycerin buffer $(\mathrm{pH}$ 8.3) that contained $0.1 \%(\mathrm{w} / \mathrm{v})$ SDS as the running buffer, as described by Laemmli (1970).

\section{Determination of kinetic parameters}

Enzyme was incubated with various concentrations of casein $(2-20 \mathrm{mg} / \mathrm{ml})$ in Tris-Hcl buffer $(\mathrm{pH} 9)$ at $50^{\circ} \mathrm{C}$. Kinetic parameters $\mathrm{K}_{\mathrm{m}}$ and $V_{\max }$ were calculated by linear regression from Lineweaver- Burk plots (Lineweaver \& Burk, 1934). Determination of temperature and $\mathrm{pH}$ optima and stability

Optimum temperature for activity of the alkaline protease was determined by carrying out at selected temperatures from 30 to $50^{\circ} \mathrm{C}$. In each case, the substrate was preincubated at the required temperature before the addition of enzyme. The optimum $\mathrm{pH}$ was determined by monitoring protease activity $\left(50^{\circ} \mathrm{C}\right)$ at $\mathrm{pH}$ values between $\mathrm{pH} 7$ and 11, using Tris-Hcl buffer $(\mathrm{pH}$ 9).

Effect of various metal ions and inhibitors on protease activity

The effects of various metal ions and inhibitors on the activity of the purified protease were assessed (including the appropriate metal ion salts) by following standard assay at $5 \mathrm{mM}$ final concentration.

\section{Compatibility with commercial detergents}

Detergents solutions at a concentration of 7 $\mu \mathrm{g} / \mathrm{ml}$ were prepared in double distilled water. The solution were boiled for $10 \mathrm{~min}$ to destroy any protease already present and cooled. Fixed enzyme concentration was added to each detergent solution and the mixture was incubated at $35^{\circ} \mathrm{C}$ for different time intervals. The activity was then assayed by Anson's method (1938).

Results and discussion

\section{Optimization of cultural parameters}

Influence of temperature and $\mathrm{pH}$ : Protease production at different temperature was examined for $72 \mathrm{~h}$ keeping the other fermentation conditions constant. Protease production increased with increase in temperature from 35 to $45^{\circ} \mathrm{C}$. Maximum production of protease $(89.1 \mathrm{U} / \mathrm{ml})$ was obtained at $45^{\circ} \mathrm{C}$. Growth and protease production ceased at higher temperature $\left(50^{\circ} \mathrm{C}\right)$ similar observation were shown by Morimura et al., (1994) for Aspergillus usami. It was revealed that environmental temperature not only affects growth rates of organism but also exhibit marked influence on the levels of protease production. Another important factor significantly affecting the production of protease is the initial $\mathrm{pH}$ of the medium. Protease production by Aspergillus niger was observed in the range $7-9 \mathrm{pH}$. Growth and protease production ceased at $9 \mathrm{pH}$. Maximum protease production $80.6 \mathrm{U} / \mathrm{ml}$ was found at $8.5 \mathrm{pH}$. The results clearly indicated alkalinophilic nature of the fungus. Optimum pH 8.4 has been reported for alkaline protease of Conidiobolus coranalis. Likewise $\mathrm{pH} 7$ has been reported to be optimum for Aspergillus flavus (Sutar et al., 1992).

Influence of carbon and nitrogen sources: There are general reports showing that different carbon sources have different influences on extracellular enzyme production by different strains (Wang \& Lee, 1996; Nehra, 2002). Among the various substrates tested mannitol and ammonium sulfate were found to be the most effective for protease production (Fig.1). The mechanism that shows the formation of extracellular enzymes is influenced by the availability of precursors for protein synthesis.

The effect of different nitrogen sources like gelatin, peptone, aspartic acid, casein and acetamide has reported that nitrogen sources

\section{Fig. 1. Effect of carbon and nitrogen sources on production of alkaline protease by $A$. niger}

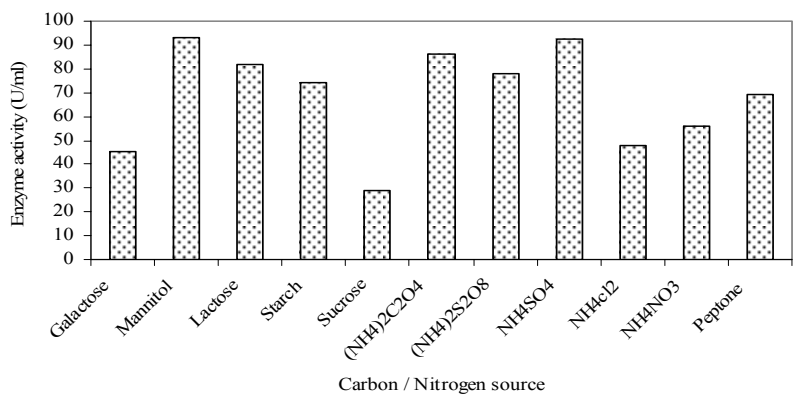

"Fungal alkaline protease"

by Kalpana Devi et al. Indian J.Sci.Technol. 
stimulate equal accumulation of protease in the culture medium of Aspergillus terreus (Ashour, et al., 1996).

Table 1. Purification of alkaline protease from Aspergillus niger

\begin{tabular}{|l|c|c|c|c|c|}
\hline \multicolumn{1}{|c|}{ Fraction } & $\begin{array}{c}\text { Activity } \\
(\mathrm{U} / \mathrm{ml})\end{array}$ & $\begin{array}{c}\text { Protein } \\
(\mathrm{mg} / \mathrm{ml})\end{array}$ & $\begin{array}{c}\text { Specific } \\
\text { Activity } \\
(\mathrm{U} / \mathrm{mg})\end{array}$ & $\begin{array}{c}\text { Purifica } \\
\text { tion } \\
(\text { fold })\end{array}$ & $\begin{array}{c}\text { Recovery } \\
(\%)\end{array}$ \\
\hline $\begin{array}{l}\text { Culture } \\
\text { filtrate }\end{array}$ & 28.0 & 5.8 & 4.82 & 1.0 & 100 \\
\hline $\begin{array}{l}\text { Ammonium } \\
\text { Sulfate } \\
\text { Precipitation }\end{array}$ & 69.3 & 2.56 & 27.07 & 5.62 & 74.25 \\
\hline Dialysis & 81.1 & 1.50 & 54.06 & 11.21 & 57.92 \\
\hline $\begin{array}{l}\text { DEAE - } \\
\text { Cellulose }\end{array}$ & 89.6 & 0.54 & 165.92 & 34.42 & 32 \\
\hline
\end{tabular}

Fig. 2. SDS - PAGE showing the molecular weight of alkaline protease enzyme produced by $A$. niger (38 kDa)

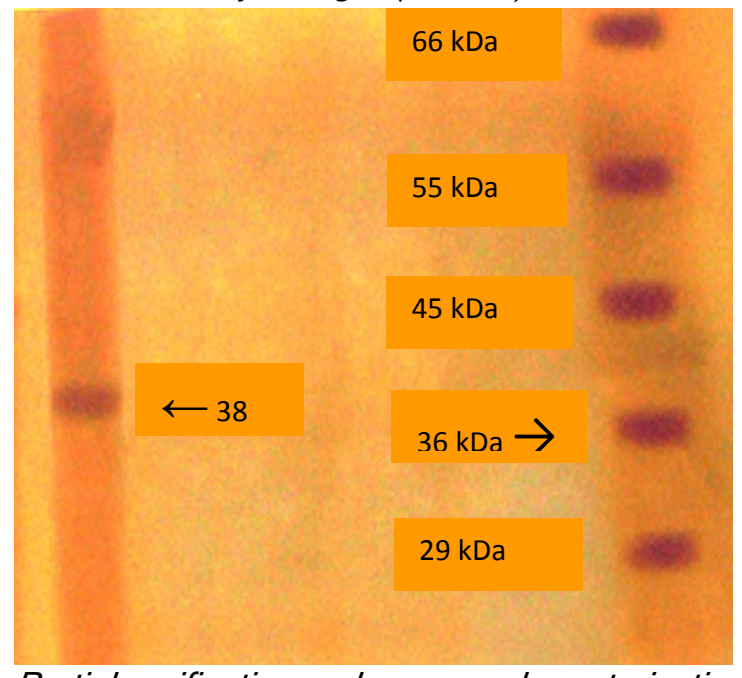

Partial purification and enzyme characterization

A summary of purification steps for alkaline protease from Aspergillus niger is given in Table 1. The purification of alkaline protease resulted in 6 fold purification with $74 \%$ recovery by ammonium sulfate precipitation. The purification of crude enzyme through DEAE cellulose column chromatography gave 34 folds increase in purity with $32 \%$ recovery of alkaline protease from Aspergillus niger. The similar observation was reported by Ogundero and Osunlaja (1986) for Aspergillus clavatus. The molecular weight of purified enzyme as determined by SDS-PAGE was found to be $38 \mathrm{kDa}$. The appearance of a single band on SDS-PAGE further suggests the enzyme to be monomeric (Fig.2). The molecular weight in the range of 32- $33 \mathrm{kDa}$ has also been reported for the enzyme from Malbranchea in/chella (Voordouw et al., 1974).

Enzyme characterization

Optimum $\mathrm{pH}$ : The effect of $\mathrm{pH}$ on the activity of alkaline protease was studied with various $\mathrm{pH}$ from 8-11 (Fig.3). The optimum pH for alkaline protease enzyme from Aspergillus niger was determined as 10.0. These findings are in accordance with earlier reports showing $\mathrm{pH}$ optima of $10.0-10.5$ for protease from Bacillus species, Thermus aquaticus, Xanthomonas maltophila and Vibrio metscnikovii (Durham et al., 1987). In an early study, the protease from Thermus sp strain RT $41 \mathrm{~A}$ exhibited stability for at least 4 hours over a $\mathrm{pH}$ range of 5-10 (Adinarayana et al., 2003). Optimum temperature:

Temperature is a critical factor for maximum enzyme activity and it is a prerequisite for industrial enzymes to be active and stable at higher temperature. Assay mixture was incubated at different temperature ranging from $30-60^{\circ} \mathrm{C}$ and enzyme activity was maximum at $45^{\circ} \mathrm{C}$ (Fig. 4). However, the enzyme was completely inactivated at $60^{\circ} \mathrm{C}$. Li et al., (1997) reported that alkaline protease isolated from Thermomyces lanuginose $\mathrm{P}_{134}$ had a broad temperature optimum of $50^{\circ} \mathrm{C}$.

\section{Fig. 3. Effect of $\mathrm{pH}$ on the activity of alkaline} protease $A$. niger

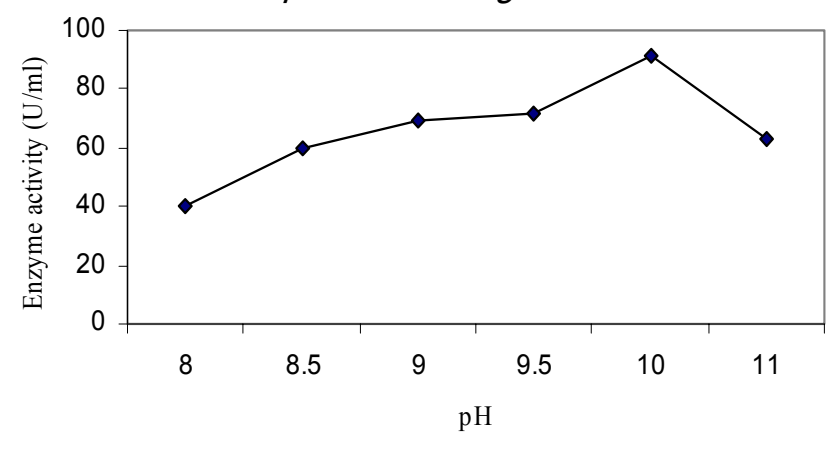

Table 2. Effect of various metal ions and inhibitors (5mM) on the activity of alkaline protease from Aspergillus niger

\begin{tabular}{|l|c|}
\hline \multicolumn{1}{|c|}{ Metal ion } & Residual activity (\%) \\
\hline None & 100 \\
\hline $\mathrm{CaCl}_{2}$ & 105.3 \\
\hline $\mathrm{MgCl}_{2}$ & 99.3 \\
\hline $\mathrm{ZnCl}_{2}$ & 21.3 \\
\hline $\mathrm{HgCl}_{2}$ & 45.8 \\
\hline $\mathrm{CoCl}_{2}$ & 2.37 \\
\hline $\mathrm{CuSo}$ & \\
\hline Urea & 63.74 \\
\hline Sodium Azide & 68.3 \\
\hline Mercaptoethanol & 69.3 \\
\hline EDTA & 61.2 \\
\hline
\end{tabular}


Samal et al., (1991) reported an alkaline protease from Tritirachium albumlimber to be quite thermostable even up to $50^{\circ} \mathrm{C}$.

The thermostability activity for alkaline protease enzyme produced by $A$. niger was stable up to 60 minutes at $40^{\circ} \mathrm{C}$. It lost activity gradually after 60 minutes (Fig. 5). The similar reports were observed

Fig. 4. Effect of temperature on the activity of alkaline protease $A$. niger

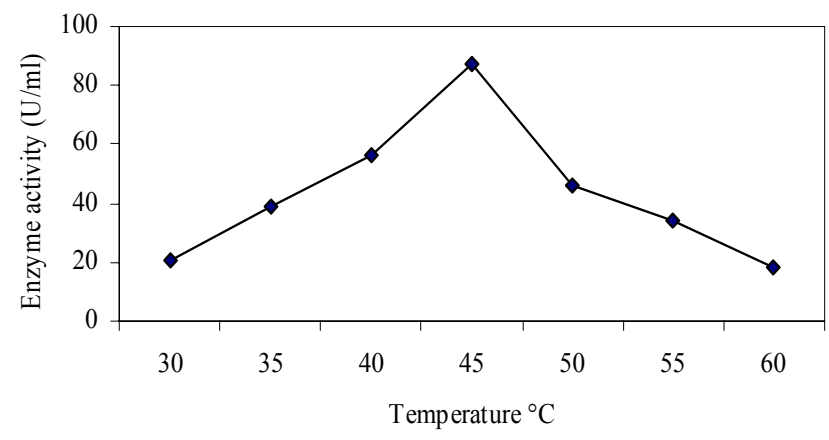

Fig. 5. Effect of incubation time on the activity of alkaline protease $A$. niger

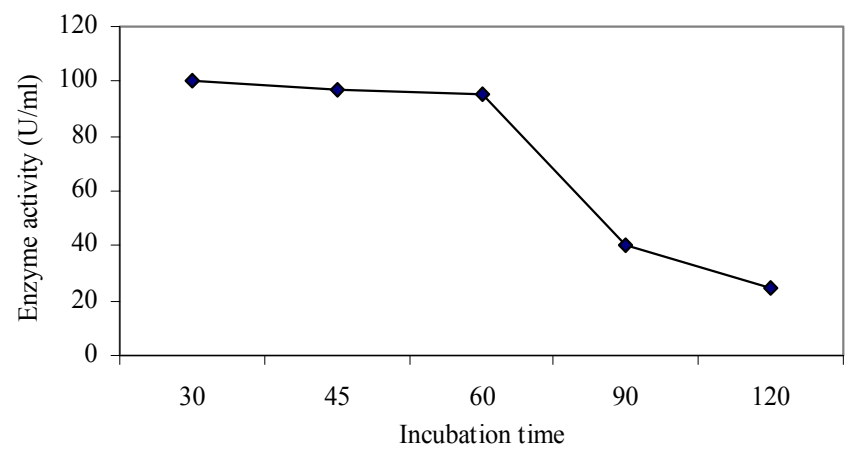

Fig. 6. Showing Alkaline protease compatible with various commercial detergents

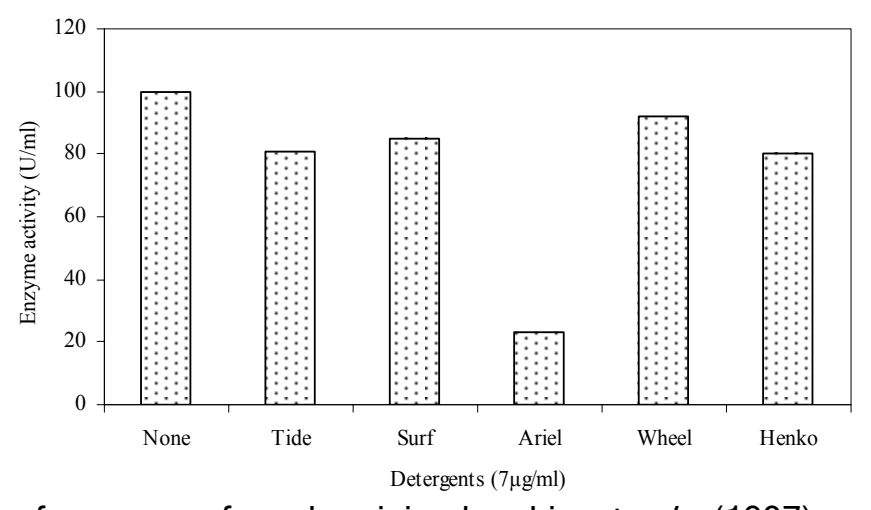

for some fungal origin by Li et al. (1997), Thermomyces lanuginosus and in Aspergillus species by Nehra et al. (2004). The results of Sumandeep et al. (1999) showed that alkaline protease appeared to be more stable at alkaline $\mathrm{pH}$
9. More than $40 \%$ of the initial activity was preserved after $1 \mathrm{~h}$ incubation with the substrate at $80^{\circ} \mathrm{C}$ in Bacillus sp.

The influence of various metal ions and inhibitors on enzyme activity was studied. Among the metal ions tested, addition of $5 \mathrm{mM} \mathrm{CaCl} 2$ enhanced the activity $105.3 \%$ of alkaline protease enzyme produced by Aspergillus niger. $\mathrm{ZnCl}_{2}$ and $\mathrm{CoCl}_{2}$ inhibited alkaline protease enzyme activity to the level of 78.8 and $97.63 \%$. Tsuchiya et al. (1987) reported protease isolated from Colosporium sp.KM388 inhibited by $\mathrm{Hg}^{++}$, $\mathrm{Mn}^{++}, \mathrm{Cu}^{++}, \mathrm{Ca}^{++}$were found to inhibit the enzyme activity of alkaline protease secreted by Bacillus polymyxa (Kaur et al., 1998). Nehra et al., (2004) reported that $\mathrm{Mg}^{++}$was found to be an activator of the alkaline protease enzyme produced by Aspergillus $s p$. The effect of inhibitors on enzyme activity of the partially purified protease from $A$. niger retained $69.3 \%$ activity when incubated in sodium azide $(5 \mathrm{mM})$ for $1 \mathrm{~h}$, as the enzyme was $90 \%$ inhibited by metal chelator EDTA. The similar results were observed by Madan et al. (2002) for Bacillus polymyxa alkaline protease (Table 2).

Effect of substrate concentration on alkaline protease activity

Optimum substrate concentration for maximum enzyme activity was determined in terms of $V_{\text {max }}$ and $K_{m}$ using casein. $V_{\max }$ and $K_{m}$ values were interpreted from Line Weaver and Eadie-Hofstee Plots (Table 3).

Optimum substrate concentration: $\mathrm{V}_{\max }$ and $\mathrm{K}_{\mathrm{m}}$ values for alkaline protease enzyme from Aspergillus niger were determined from Line Weaver and Eadie-Hofstee plots. The results revealed that alkaline protease from Aspergillus niger had a $\mathrm{V}_{\max }$ of $85.0 \mathrm{U} / \mathrm{mg}$ of protein and $\mathrm{K}_{\mathrm{m}}$ value of $0.8 \mathrm{mg} / \mathrm{ml}$. Matta et al., (1994) has reported proteases with lower $\mathrm{K}_{\mathrm{m}}$ values with casein substrate from Bacillus alkalophilus and Pseudomonas species, which showed $\mathrm{K}_{\mathrm{m}}$ values of 0.4 and $2.5 \mathrm{mg} / \mathrm{ml}$ respectively. A slightly higher $\mathrm{K}_{\mathrm{m}}$ value of $3.7 \mathrm{mg} / \mathrm{ml}$ has been reported for the enzyme from Bacillus polymyxa strain indicating higher affinity of the enzyme towards casein (Kaur et al., 1998).

Application study

Compatibility with various commercial detergents: Enzyme activity and stability in presence of some available commercial detergents was studied with a view to exploit the enzyme in detergent industry. The enzyme retained $80-92 \%$ of its original activity in various detergents (Fig. 5\&6). However, Arial detergents retained only $23 \%$ of enzyme activity. Phadatare et al. (1993) reported high activity alkaline protease 
Table 3. Properties of alkaline protease enzyme

\begin{tabular}{|l|c|}
\hline \multicolumn{1}{|c|}{ Properties } & Aspergillus niger \\
\hline Optimum $\mathrm{pH}$ & 8.5 \\
\hline Optimum temperature $\left({ }^{\circ} \mathrm{C}\right)$ & 45 \\
\hline Thermo stability (minutes) & 60 \\
\hline $\mathrm{V} \mathrm{max} \mathrm{(U/mg} \mathrm{protein)}$ & 85 \\
\hline $\mathrm{Km}(\mathrm{mg} / \mathrm{ml})$ & 0.8 \\
\hline Molecular weight(kDa) & 38 \\
\hline
\end{tabular}

from Conidiobolus coranatus showed compatibility at $50^{\circ} \mathrm{C}$ in the presence of $25 \mathrm{mM}$ Calcium chloride with a variety of commercial detergents. They observed the enzyme protease to retain more than $80 \%$ of its activity in the presence of various detergents. Similarly, among the three proteases isolated from Tritirachium album Limber, proteinase $\mathrm{R}$ and $\mathrm{T}$ were reported to retain 90 and $89 \%$ activity respectively up to one hour in the presence of detergents like ERA plus, Dyanamo, while BPN was highly unstable in all the detergents and retained just $4 \%$ activity even after 10 minutes. Madan et al., 2002 studied the compatibility of alkaline protease from Bacillus polymyxa retained $20-84.5 \%$ of its activity in various detergents. They also reported 16, 11.4 and $6.6 \%$ activity in Revel, Ariel and wheel respectively (Adinarayana, 2003).

\section{Acknowledgements}

The authors are sincerely grateful to the Management, Karpagam University, Coimbatore, Tamil Nadu, India for encouragement and support.

\section{References}

1. Abraham LD and Breuil C (1996) Isolation and characterization of a subtilisin like serine proteinase secreated by the Sap staining fungus Ophiostoma piceae. Enzyme Microbio. Technol.18, 133-140.

2. Adinarayana K (2003) Purification and characterization of thermostable serine alkaline protease from a newly isolated Bacillus subtilis. PE-11. AAPS Pharmascitech. 56, 245-250.

3. Agarwal D, Patidar P, Banerjee $T$ and Patil $S$ (2004) Production of alkaline protease by Penicillium sp. Under SSF conditions and its application to soy protein hydrolysis. Process Biochem. 39, 977-981.

4. Anson ML (1938) The estimation of pepsin, trypsin, papain and cathepsin with haemoglobin. J.Gen.Physiol. 20, 79-89.

5. Ashour SA, EL Shore HM, Metwally M, and Habib SA (1996) Fungal fermentation of Whey incorporated with certain supplements for the production of protease. Microbios. 86, 59-69.

6. Bhosale SH, Rao MV, Deshpande VV, and Srinivasan MC (1995) Thermostability of high activity alkaline protease from Conidiobolus coroinatus $\quad[\mathrm{N}(\mathrm{L}) 86.8 .20]$ Enzyme Microbio. Technol. 17, 136-139.

7. Breuil C and Huang J (1994) Activities and properties of extracellular proteinases produced by staining Dungigrwon in protein supplemented liquid media. Enzyme Microbio. Technol. 17, 136-139.

8. Durham DR, Stewart DB and Stellwag EJ (1987) Novel alkaline and heat stable serine protease from alkalophilic Bacillus sp. Strain GX 6638. J.Bacteriol. 169, 2762-2768.

9. Hajji M, Kanoun S, Nasri M and Gharsallah N (2007) Purification and characterization of an alkaline serine-protease produced by a new isolated Aspergillus clavatus ES1. Process Biochem. 42, 791-797.

10. Hajji M, Rebai A, Gharsallah $N$ and Nasri $M$ (2008) Optimization of alkaline protease production by Aspergillus clavatus ES1 in Mirabilis jalapa tuber powder using statistical experimental design. Appl. Microbiol. Biotechnol. 79, 915-923.

11. Kaur M, Dhillon S, Chaudhary $K$ and Singh $K$ (1998) Production, Purification and characterization of a thermostable alkaline protease from Bacillus polymyxa. Ind.J.Microbiol. 38, 63-67.

12. Kumar A, Sachdev A, Balasubramanyam SD, Saxena AK and Lata (2002) Optimization of Conditions for Production of Neutral and Alkalineprotease from species of Bacillus and Pseudomonas. Ind.J. Microbiol. 42, 233-236.

13. Laemmli UK (1970) Cleavage of structural protein during the assembly of head of bacteriophage $\mathrm{T}_{4}$. Nature. 227, 680-685.

14. Li DC, Yang YJ and Shem CY (1997) Protease production by the thermophilic fungus Thermomyce lanuginosus. Myco.Res. 101, 18-22.

15. Lineweaver $H$ and Burk D (1934) The determination of enzyme dissociation constant. J.Am. Chem. Soc. 56, 658-666.

16. Lowry $\mathrm{OH}$, Rosebrough $\mathrm{NJ}$, Farr $\mathrm{AC}$ and Randall RJ (1951) Protein measurement with the Folin-phenol reagent. J.Biol. Chem. 193, 265-275.

17. Madan M, Dhillon S and Singh R (2002) Production of alkaline protease by a UV mutant of Bacillus polymyxa. Ind. J. Microbiol. 42, 155159.

18. Manachini PL, Fortina MG and Parini C (1988) Thermostable alkaline protease produced by Bacillus thermorubera new species of Bacillus. Appl.Microbiol. Biotechnol. 28, 409-413.

19. Matta H, Punj V and Kalra MS (1994) Isolation and partial characterization of heat stable 
extracellular protease from Pseudomonas sp.AFT 36. Milchwissenschaft. 49, 186-189.

20. Morimura S, Kida and Sonada Y (1994) Production of protease using waste water from the manufacture of Shochu. J.Ferment.Bioeng. 77, 183-187.

21. Mulimani.VH, Patil GN and Prashanth SJ (2002) Bleach stable and Alkali-Tolerant Protease from Aspergillus flavus. Ind.J. Microbiol. 42, 55-58.

22. Nehra KS, Dhillon S, Chaudhary K and Singh $\mathrm{R}$ (2002) Production of alkaline protease by Aspergillus species under submerged and solid state fermentation. Ind.J. Microbiol. 42, 43-47.

23. Nehra KS, Singh A, Sharma J, Kumar R and Dhillon S (2004) Production and characterization of alkaline protease from Aspergillus species and its compatability with commercial detergents. Asian J. Microbiol.Biotech.Env.Sc.6, 67-72.

24. Ogundero VW and Osunlaja SO (1986) The purification and activities of an alkaline protease of A.clavatus from Nigerian poultry feeds. J.Basic Microbiol. 26, 241-248.

25. Palaniswamy M, Pradeep BV, Sathya R and Angayarkanni J (2008) Isolation, identification and screening of potential xylonolytic enzyme from litter degrading fungi. African J. Biotech. 7, 1978-1982.

26. Phadatare SU, Deshpande VV and Srinivasan MC (1993) High activity alkaline protease from Conidiobolus coronatus (NCL 86-8.20) Enzyme production and compatability with commercial detergents. Enzyme Microbio. Technol. 15, 72-76.

27. Prakasam RS, Rao CS and Sarma PN (2005) Green gram husks an inexpensive substrate for alkaline protease production by Bacillus sps in solid state fermentation. Bioresourse
Technol. 28, 1449-1454.

28. Rao MB, Tanksale AM, Ghatge MS and Despande VV (1998) Molecular and biotechnological aspects of microbial proteases. Microbiol Mol. Biol. Rev. 62, 597635.

29. Samal BB, Karan B, Parker C and Stabinsky $Y$ (1991) Isolation and thermal stabilities of two novel serine proteinases from the fungus Tritirachium album Limber. Enzyme Microbio. Technol. 13, 66-70.

30. Sandhya C, Sumantha A, Szakacs G and Pandey A (2005) Comparative evaluation of neutral protease production by Aspergillus oryzae in submerged and solid-state fermentation. Process Biochem. 40, 26892694.

31. Sumandeep, Bhushan B, Beg QK and Hoondal GS (1999) Partial purification and characterization of a thermostable alkaline protease of an alkalophilic Bacillus sp. NG 27. Ind.J. Microbiol.39, 185-187.

32. Sutar II, Srinivasan MC and Vartak HG (1992) Production of an alkaline protease from Conidiobolus coranatus and its use to resolve DL-phenylalanine and DLP-phenylglycine. $W$. J. Microbiol.Biotechnol. 8, 254-258.

33. Tsuchiya K, Arai $T$, Seki $K$ and Kimura $T$ (1987) Purification and some properties of alkaline protease from Cephalosporium sp. KM 338. Agric.Biol.Chem. 51, 2959-2965.

34. Voordouw GG, Gaucher M and Roche RS (1974) Anomalous molecular weight of protease in gel chromatography. Biochem.Biophys.Res.Commun. 58, 8-12.

35. Wang $Y$ and Lee $M$ (1996) Influence of culture and nutritional condition on the production of protease from Thermophilic strain Aspergillus species NTIJ-FC-671. J.Chinese Agric.Chemical.Society. 34, 732-742. 